\title{
A STUDY OF BUILDING INFORMATION MODELING (BIM) UPTAKE AND PROPOSED EVALUATION FRAMEWORK
}

\author{
SUBMITTED: April 2020 \\ REVISED: August 2020 \\ PUBLISHED: September 2020 \\ EDITOR: Žiga Turk \\ DOI: $10.36680 /$ j.itcon. 2020.026
}

\author{
Bahriye Ilhan Jones, Assistant Professor \\ Department of Architecture, Istanbul Technical University \\ ilhanba@itu.edu.tr and http://arch.itu.edu.tr/
}

\begin{abstract}
SUMMARY: Although BIM provides various benefits to the architecture, engineering, construction and facilities management (AEC/FM) industries, it lacks wider and comprehensive utilisation. This study assesses the understanding and perception of BIM uptake in UK architectural offices. The aim is to analyse and compare BIM adoption at the organisational level for the years 2011, 2014 and 2018 as well as to form the basis for an evaluation structure of its utilisation. The objectives of the study are to examine the level of BIM adoption and capability of UK architectural offices and to investigate the drivers and barriers to BIM usage. The research is based on online questionnaires made available to all Royal Institute of British Architects (RIBA) chartered members. The data are analysed through descriptive statistics, analysis of variance (ANOVA), regression and cross-tabulation. The results are discussed in terms of BIM usage and BIM readiness with regard to the company profiles. Companies are motivated to utilise BIM technology due to its facilitation of effective teamwork and project efficiency. However, the need for extensive training, a general lack of demand and its perceived sophistication in relation to day-to-day tasks are reasons why the use of BIM is avoided. The study concludes with key learning points from the questionnaire depending on three different years and the proposed evaluation framework to achieve improved utilisation of BIM.
\end{abstract}

KEYWORDS: BIM, building information modelling, comparative analysis, evaluation framework, questionnaire, UK architectural offices.

REFERENCE: Bahriye Ilhan Jones (2020). A study of Building Information Modeling (BIM) uptake and proposed evaluation framework. Journal of Information Technology in Construction (ITcon), Vol. 25, pg. 452468, DOI: 10.36680/j.itcon.2020.026

COPYRIGHT: (C) 2020 The author(s). This is an open access article distributed under the terms of the Creative Commons Attribution 4.0 International (https://creativecommons.org/licenses/by/4.0/), which permits unrestricted use, distribution, and reproduction in any medium, provided the original work is properly cited. 


\section{INTRODUCTION}

The changing trends in the architecture, engineering, construction (AEC) and facilities management (FM) domains necessitate more collaborative practices for building design and construction. Rapid advancement of technology continues to leverage change and innovation in the construction industry (Ghaffarianhoseini et al, 2017). Building Information Modeling (BIM) is accelerating the pace of this positive change and there has been a growing trend towards BIM utilisation. It represents a significant opportunity to overcome the sector's resistance to change and innovation, which have been hindering the modernisation of the industry (Ahmed and Kassem, 2018). Since BIM provides coordinated, consistent and computable building information management from design to construction and maintenance, and for the operation stages of a building's lifecycle, many researchers and practitioners believe the application of BIM can be beneficial to the AEC/FM industry (Lee and Yu, 2015). Many reports indicate that the BIM market will be huge, but its adoption rate in many countries is very low compared with the adoption of Information and Communications Technology (ICT) in other industries (Xu et al, 2014). Understanding the current level of BIM in organisations and even countries is important for determining directions for future development (Jung and Lee, 2015) since the use of BIM is not the same extensive in countries all around the world (Sanchís Pedregosa et al, 2020).

The benefits of BIM technologies have been recognised by various governments (Eadie et al, 2015), and many of them have initiated the necessary steps to facilitate the use of BIM. The governmental institutions in the Nordic countries are interested in bringing the construction industry to a higher level of technological operability (Hermund, 2009). The Finnish AEC industry, as a pioneer in BIM, has required Industry Foundation Classes (IFC) including BIM modeling for public sector projects through Senate Properties since 2007 (Smith, 2014). In Norway, Statsbygg, a firm responsible for construction, management and development of government facilities, uses BIM in its projects and building processes (Mulenga and Han, 2010). The vision of digital construction, a part of the 'Will to growth' package launched by the Danish government in 2002, is a process where all participants in a building project, architects, engineers, contractors and suppliers, contribute to the overall amount of data that represents the construction project (Jensen and Johannesson, 2013). The US General Services Administration (GSA) encourages the application of BIM in public projects for spatial program analysis and 4D modeling (Matta, 2016). The Singapore Building and Construction Authority (BCA) have developed a strategy to have BIM widely implemented on public projects by 2015 and the BIM fund under the Construction Productivity and Capability Fund (CPCF) was established to help firms adopt BIM (Building and Construction Authority, 2018). Moreover, there have been government mandates to use BIM technology on public projects in South Korea, Hong Kong, France, the Netherlands, Qatar and Kuwait (Giacomo, 2015). The UK Government believes that the use of BIM brings many efficiencies and benefits across the project lifecycle and they set a target of Level 2 BIM adoption for UK construction processes in 2011. The public sector was required to have fully collaborative 3D BIM on all centrally procured construction contracts by 2016 (Government Construction Strategy, 2012). The mandate, which has been in place since April 2016 requires that all projects funded by central government be delivered with 'fully collaborative 3D BIM'. It is not the law that the design and construction team use BIM, instead, using BIM is a contractual condition of working with the UK's largest client, central government (Malleson, 2018). The growth in awareness and use of BIM and simultaneously, the transformation of the construction industry (partly enabled by BIM) to embrace digital ways of working (Bain, 2019) can be counted as the results of such policies.

As a saturated market, however, the UK construction industry faces some challenges such as poor productivity and profitability, unskilled and aging workforce, project performance despite the growing technological opportunities. To be competitive the organisations have to adopt digital collaboration tools as well as advanced technologies. Exploring the status of BIM technology implementation which is a small but primal step towards more digitalised working environments, is the main driver of this research. The UK is likely to be a good indicator of future uptake in other countries since the UK AEC industry is typically quick to embrace technology-oriented approaches. Together with the recent BIM mandate, being one of the early leaders for the adoption, the UK serves as a good model to examine the uptake of BIM as well as the difficulties in its implementation. This paper focuses on the BIM situation within UK architectural offices through online questionnaire and proposes an evaluation framework. The study not only identifies the current state of BIM realisation, but also makes a historical comparison of BIM usage. It focuses on the reasons behind adopting or resisting BIM, which highlights the key issues that other countries may face when they adopt BIM in the future. Such a research bridges the gap between the strategy for BIM usage and its practical consequences. 


\section{BACKGROUND}

Several previous studies have focused on the current state of BIM in different countries. These also explore the motivation to use, challenges faced during and success factors of BIM technology. Georgiadou (2019) outlines the general status quo of BIM adoption and maturity in the UK residential projects based on an online survey and complementary semi-structured interviews with building professionals. The findings suggest that the most frequently reported benefits are related to collaboration and the blend of product (software) and process innovation, whilst lifecycle thinking and waste reduction are often overlooked, and despite the widespread awareness on BIM, there is a financial barrier to invest in developing digital potentials, particularly for small and medium sized enterprises. Alreshidi et al (2018) conducted a questionnaire among practitioners in the UK construction industry and revealed the key findings as: Construction industry still faces many issues and barriers with respect to socioorganisational (e.g. people resistance to change), legal (e.g. lack of defined liability for wrong or incomplete information input), financial (e.g. training cost), and technical (e.g. lack of technical training) that lead to negative impacts on team collaboration during the project. Blay et al (2019) aim to validate the perceived benefits and challenges for managing change in BIM Level 2 in the UK through a combination of a questionnaire and interviews with BIM Level 2 practitioners. The study also identifies additional benefits and challenges, such as cost saving and risk reduction (benefits) and social dimension issues in the processes (challenges).

In Europe, the main barriers to BIM adoption by a questionnaire disseminated in all EU countries in 2017 are highlighted and compared with the barriers described by academics (Charef et al, 2019). Samuelson and Björk (2014) found out that the adoption of the more complex applications (e.g. BIM) is slow based on the results of a longitudinal survey-based study of information technology use in the Swedish building industry, despite the broad consensus about its being an effective work method and given the highest priority of all among architects. BoschSijtsema et al (2017) explore the current use and perceived constraints and driving forces of BIM implementation with respect to Swedish mid-sized contractors. Visualization, which also facilitates coordination and communication, is the most commonly used application whilst the biggest perceived constraints involved partners that did not use BIM, lack of demand from clients, and the absence of internal demand in the company. The most common driving forces included the fact that BIM is perceived as a means to follow technical development and that BIM provides competitive advantages to the company. Furthermore, BIM adoption drivers in Dutch construction (Papadonikolaki, 2018) and barriers to BIM implementation in renovation processes in the Italian Market (Elagiry et al, 2019) are emphasised.

Similarly, studies focusing on the situation in the Far East include the benefits, difficulties and critical success factors (CSFs) of BIM. Chan et al (2019) identify and assess the perceived benefits of and barriers to BIM implementation in the Hong Kong construction industry through a structured empirical questionnaire. Cultural barrier (resistance to change), organizational structure that does not support BIM, insufficient interoperability of computer software, lack of industry standards, and difficulties in measuring impacts of BIM are the most profound barriers whereas the five most important benefits include better cost estimates and control, better understanding of design, reduce construction cost, better construction planning and monitoring, and improvement of project quality. Based on two surveys, Yang and Chou (2018) discuss and compare the status of BIM applications from government sectors in Taiwan for the years of 2015 and 2016. For both years, the top recognized benefit is reduced errors and omissions in construction documents and the benefits with lower percentages are maintaining repeat business with past clients, and recruiting and retention of staff. Chien et al (2014) identify the critical risk factors of BIM projects in Taiwanese AEC industry and concluded that inadequate project experience and lack of available skilled personnel are the factors that affect other risk factors; thus, allocating management resources to addressing these risk factors should be a priority. Tsai et al (2014) conduct a survey in Taiwan's AEC industry 2011 to propose an approach for developing CSFs that can be further developed for the assessment of BIM adoption at organizational level. Ding et al (2015) identify the key factors affecting architects' intention to adopt BIM in the Chinese design firms. Based on the questionnaire results, they list the economic benefits, effectiveness and efficiency of BIM adoption as the sources of motivation whereas technical issues associated with BIM, and BIM capability of a project team as the influencers on architects' BIM adoption. Management support and knowledge structure are not critical for architect's intention to adopt BIM. Based on the data collected from BIM engineers, Wang and Song (2017) examine the influence of five potential variables on BIM user satisfaction in China. The results show that the perceived usefulness, top management support and management by objective are significantly associated with BIM user satisfaction, and the influence of management by objective on BIM user satisfaction is much stronger than the other two. Besides, perceived ease of use and attitude have a significant influence on 
perceived usefulness. Son et al (2015) examine the factors that can potentially facilitate architects' adoption of BIM through a survey in Korea. The results reveal that top management support, subjective norm, compatibility, and computer self-efficacy are critical factors affecting architects' behavioural intentions to adopt BIM.

Babatunde et al (2020) discuss BIM from a developing country perspective. They empirically analyse the drivers to BIM adoptions in AEC firms in Nigeria. According to the questionnaire results; the top six total ranked drivers to BIM adoptions include desire for innovation to remain competitive; time savings; improving communication to operatives; accurate construction sequencing and clash detection; streamlining design activities and improving design quality; and client/competitive pressure. In their earlier research, Babatunde et al (2018) identify the top six ranked BIM benefits as: BIM provides fast, effective and efficient quantity take-off and cost estimation; improve cost database management which reduces loss of information; produce reliable and accurate quantities as well as competitive cost estimates; enhance communication and collaboration amongst team members; time savings in the preparation of estimating costs; and it generate accurate cost estimates for various design alternatives.

Based on studies evaluating the value of BIM on project performance (Barlish and Sullivan 2012, Davies and Harty 2013, Sackey et al 2014), the underlying argument is that BIM is potentially useful, but that individuals and organizations first have to learn how to use the new technology to reap the true benefits of implementing BIM (Smits et al, 2017). The previous studies identify the current awareness/use of BIM and influencing factors/major barriers to BIM adoption and implementation; and the efforts taken to measure and evaluate the value of BIM utilisation are limited. However, defining a true gauge of BIM adoption is of great importance for maximising its benefits. Jin et al (2017) also state a comprehensive evaluation of BIM at the company level is considered a major difficulty of implementing BIM. This study intends to fill this gap by measuring BIM usage and its effects in the UK and developing an evaluation framework. BIM is examined over a period of time through the same set of questions in order to see whether BIM is a technology that is actively being adopted. Beyond being just a historical comparison, it also aims to provide policy makers with a guide for planning the way ahead in the UK and other countries.

The main goal of the study is to assess the BIM uptake at the organisational level in the UK AEC industry and to present an evaluation framework for BIM adoption and implementation available to any other nation and/or organisation. To this end the specific objectives are (1) to examine the BIM experience and capability of UK architectural offices and to determine their adoption level and (2) to investigate the drivers and barriers to BIM adoption and usage.

\section{RESEARCH METHODS}

To obtain the desired data for this study, an online questionnaire was used. Online or web-based questionnaires have become a preferred approach in the research community and the business world (Wu and Issa, 2013). Typical advantages of online questionnaires compared with traditional methods include low cost, ease of deployment, flexibility, question diversity, speed and timeliness (Evans and Mathur, 2005). A web-based survey package (Google Forms) was used to disseminate the questionnaire to gather the information from respondents due to its flexibility. The structure of the questionnaire was developed to assure data comparison, accuracy of recording and easy data processing. Using a Likert-type scale with 1 representing 'strongly disagree' and 5 representing 'strongly agree', survey respondents were requested to answer questions regarding their awareness of current status and issues surrounding BIM adoption and usage.

The research was carried out in four stages: (1) Based on the research objective and previous literature, the questionnaire was developed and pre-tested to confirm that the statements were easily understood. (2) The questionnaire was conducted on all Royal Institute of British Architects (RIBA) chartered members. (3) Data were collected in 2011, 2014 and 2018 with an interval of approximately 3.5 years between samples. (4) Obtained data were analysed using SPSS Statistics software (V25.0) (Fig. 1). An interval of 3.5 years was selected to provide sufficient resolution for the comparative study without placing unreasonable demands on volunteer's time. Starting from 2010, BIM has been intensively discussed in both academia and the industry, thus, 2011 is important for BIM update. 2018, on the other hand, is critical to assess the impact of 2016 BIM mandate. The same questionnaire was used to be able to compare the results of the research. 


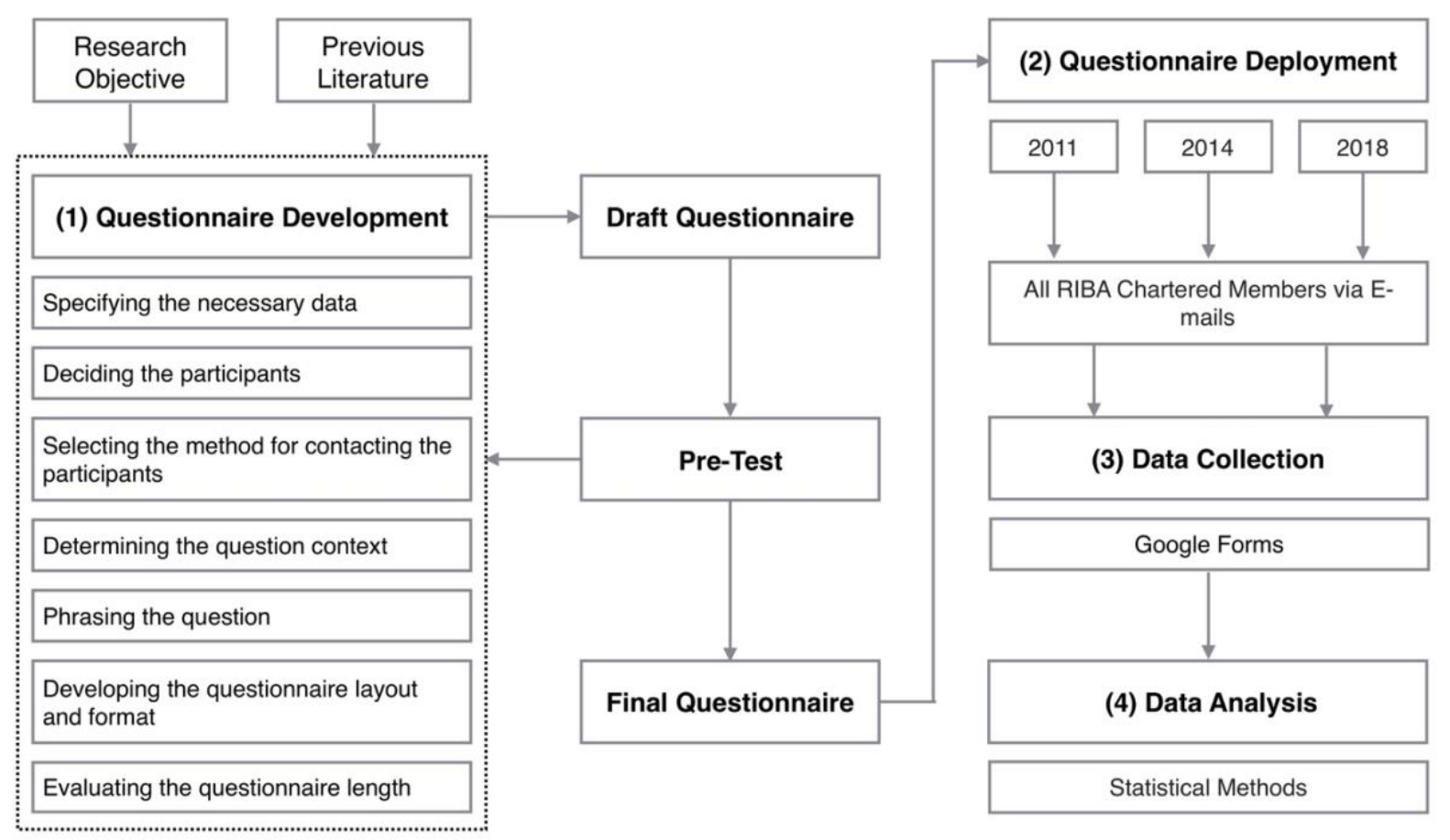

FIG. 1: Research methods.

\section{QUESTIONNAIRE DESIGN AND SAMPLING}

The questionnaire was designed to cover different aspects of BIM and was divided into two parts based on the two objectives: (1) Breaking down the adoption by company size and age and (2) addressing the perceived drivers and barriers to BIM adoption by underlying the motivation. After requesting the demographic information including age, gender, educational background and position within the company, respondents were then asked to give company age, services provided, project types, mean size of the projects, number of employees and annual turnover information in the first part. Depending upon the company's BIM technology utilisation, the second part directs the respondents to separate subsets of questions. The BIM usage and adoption subsection measures BIM utilisation within the company, whereas the BIM readiness subsection focuses on the reasons for not using BIM and ascertains intentions to use BIM in the future. Both parts investigate the same concerns depending on whether BIM is already applied or not (Fig. 2). Questions prepared partly aligned with similar studies provide to facilitate comparison and a continuity of literature, so it is not completely disjoint.

This study targeted all UK RIBA chartered practices providing architectural services and specialist services such as building services engineering, cost estimation, project management and surveying. In 2011, a total of 2803 companies were included, increasing to 3069 in 2014 and 3752 in 2018. The company information was gathered from the RIBA website. A total of 125 companies responded to the questionnaire, with 43 participating in 2011; 37 in 2014 and 45 in 2018 without any overlap. In order to ensure the validity and consistency of the statistical analysis, reliability analysis is performed initially, and then the hypotheses are tested. Table 1 shows the demographic attributes of the respondents. The majority of the respondents were male with $93 \%, 87 \%$ and $82 \%$ rates respectively. The mean age of the sample was 53 for 2011; 50 for 2014 and for 51 for 2018. In 2011 and 2018 most respondents were architecture graduates, in 2014 all respondents were architects. Most of the respondents specified 'director' as their position in the organisation for all years analysed. 


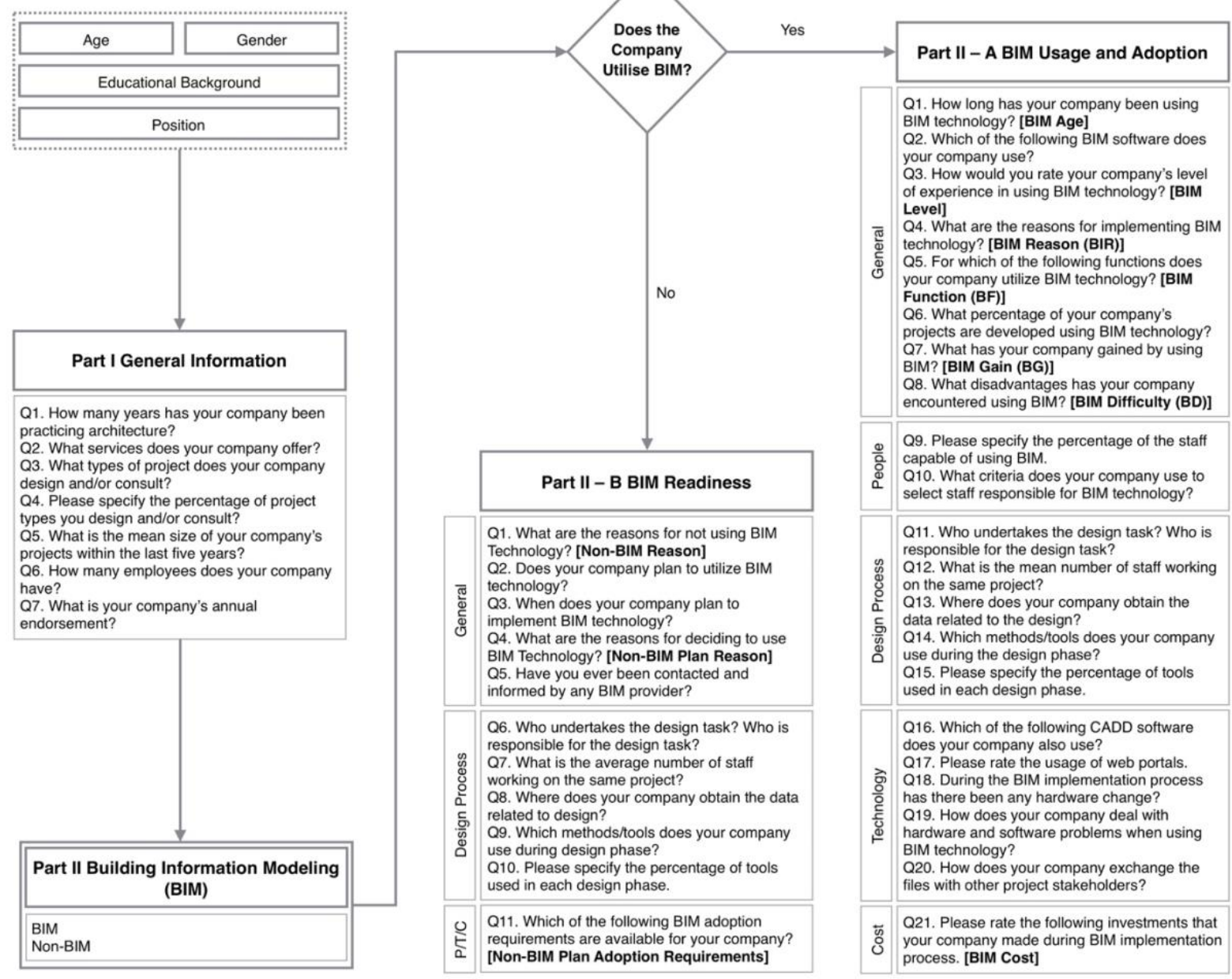

FIG. 2: Questionnaire design.

TABLE. 1: Demographic characteristics of the respondents.

\begin{tabular}{|c|c|c|c|c|c|c|c|c|c|c|c|c|c|c|c|c|c|c|}
\hline & \multicolumn{2}{|c|}{ Gender } & \multicolumn{3}{|c|}{ Age } & \multicolumn{5}{|c|}{ Education } & \multicolumn{8}{|c|}{ Position } \\
\hline & $\frac{\frac{0}{\pi}}{\Sigma}$ & 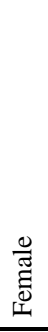 & $\begin{array}{l}\text { f } \\
\text { ̀े }\end{array}$ & $\begin{array}{l}\stackrel{8}{1} \\
\frac{1}{\gamma}\end{array}$ & $\stackrel{8}{\circ}$ & 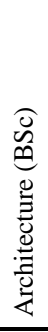 & 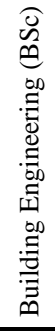 & 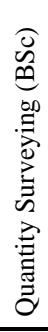 & $\mathscr{n}_{\Sigma}^{\mathscr{L}}$ & 롤 & $\sum_{0}^{\bar{\Xi}}$ & 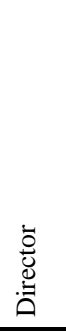 & 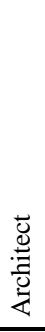 & 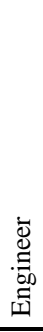 & 离 & 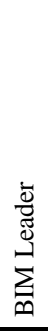 & 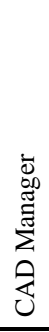 & 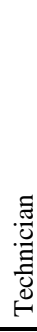 \\
\hline 2011 & 40 & 3 & 6 & 24 & 13 & 36 & 6 & 1 & 8 & 1 & 3 & 27 & 2 & 1 & 7 & 2 & 1 & 0 \\
\hline 2014 & 32 & 5 & 8 & 18 & 11 & 37 & 0 & 0 & 7 & 0 & 1 & 20 & 2 & 0 & 10 & 2 & 0 & 2 \\
\hline 2018 & 37 & 8 & 12 & 18 & 15 & 44 & 1 & 0 & 11 & 2 & 5 & 20 & 7 & 1 & 5 & 4 & 1 & 2 \\
\hline
\end{tabular}




\section{DATA ANALYSIS}

Since there are several categorical variables, ANOVA tests are frequently used to analyse the data. ANOVA tests the effect of a categorical independent variable on a dependent variable. The hypotheses in ANOVA tests are as follows:

$$
H_{0} \text { : The means of all groups under consideration are equal. }
$$

$H_{a}$ : The means of all groups under consideration are not all equal.

The intuition behind ANOVA is that if the variability between groups is large relative to the variability within groups, then the data suggest that the means of the populations from which the data were drawn are significantly different. ANOVA tests can be used when the independent variable is categorical. Furthermore, regression model (1) is used to investigate non-categorical variables' effect on dependent variable.

$$
\text { dependent varible }{ }_{i}=\beta_{0}+\beta_{1} * \text { independent variable }+\beta_{2} * \text { control variable }
$$

In this model, the significance of the coefficients of independent and control variables show whether these variables have a significant effect on the dependent variable.

\subsection{Findings and discussion}

The findings of this study are presented in three parts. The first part presents descriptive data, while the second and third concern the comparison between 2011, 2014 and 2018 data for BIM users and non-users respectively through analysis of variance (ANOVA), regression and cross-tabulation analyses.

\subsubsection{Descriptive results}

The primary examination of data is for the utilisation of BIM and general information on the companies that use BIM technology. Fig. 3 shows the distribution of the companies that utilise BIM technology while the distribution of the companies that plan to implement BIM technology is given in Fig. 4. The percentage of BIM utilisation increased over the years whereas the percentage of the companies that plan to implement BIM technology, fluctuates. Despite the growing interest in BIM, its utilisation still remains limited. This deduction is consistent with the findings from Georgiadou (2019) and Samuelson and Björk (2014).

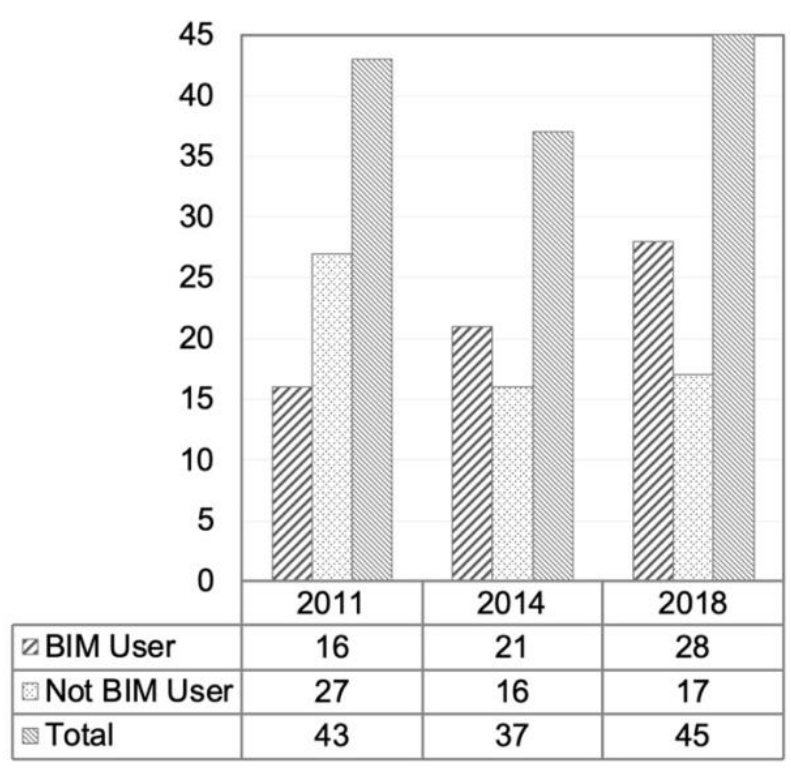

FIG. 3: Distribution of the companies in terms of BIM utilisation. 


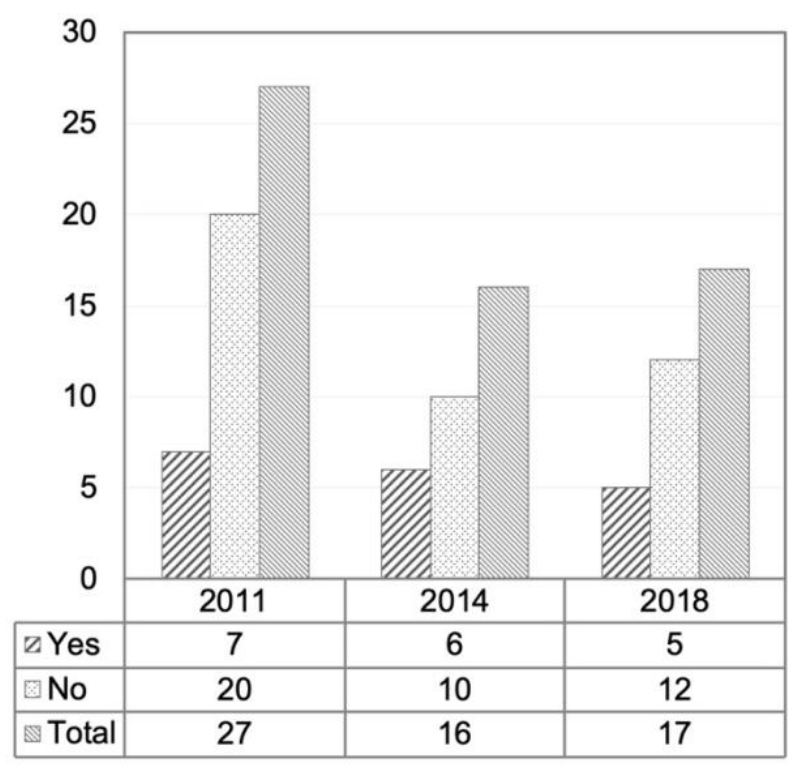

FIG. 4: Distribution of the companies in terms of BIM utilisation plan.

Fig. 5 presents the general information, such as company age, the mean size of the projects within the last five years, employee number and annual turnover of the companies that use BIM.

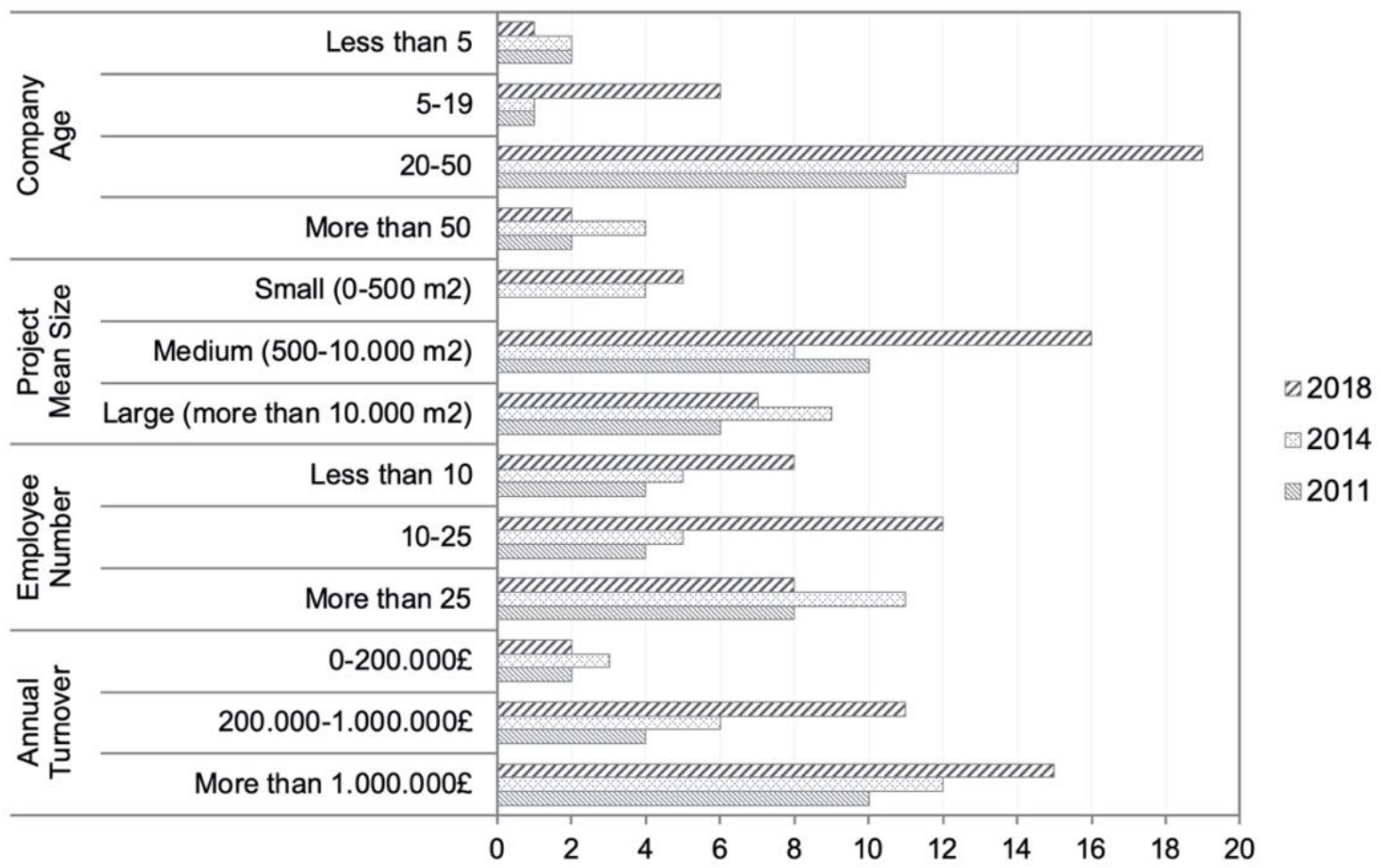

FIG. 5: General information on the companies using BIM technology.

Contrary to expectations, starting from 2014, companies indicated that they utilised BIM technology for also their small sized projects. Similarly, rate of BIM usage at companies with fewer than 10 employees has increased over the years. This shows that regardless of company or project size, BIM has started to be embraced within the industry. 2011 and 2014 users are new adopters using BIM technology for less than a year whereas 2018 users have more equally distributed among BIM experience. The company's level of experience in using BIM technology and BIM age are mostly in a proportional relationship. Companies with more BIM experience rated their BIM level as expert. Distinctively, 2011 companies with less BIM practice regard themselves either as advanced or expert. This may have been caused by user overconfidence during the early adoption of BIM. 


\subsubsection{BIM users}

This section compares 2011, 2014 and 2018 data through ANOVA and regression analyses for BIM users. The reliability analysis for the scale consisting of 21 questions applied to BIM users shows that the questionnaire has good reliability with a Cronbach's Alpha score of 0.855 . Note that there is no widely accepted standard interpretation of Cronbach's alpha value. Values below 0.5 do not indicate that the data are reliable, whilst values above 0.9 are generally considered to indicate high reliability for unidimensional data. In this study it is assumed that a Cronbach's alpha of 0.80 and above is good and $\geq 0.70$ is moderate.

To meet the objectives of the research, which are examining the BIM experience and capability of UK architectural offices, determining their adoption level and investigating the drivers and barriers to BIM usage, the following relationships are determined:

- $\quad$ BIM utilisation and year;

- The impact of year on BIM reason, BIM function, BIM gain, BIM disadvantages and BIM cost;

- $\quad$ Year, BIM age and BIM satisfaction;

- $\quad$ Year, BIM age and BIM difficulty;

- $\quad$ BIM level and BIM function.

Table 2 reveals these relationships through the hypothesis, test used and results for each factor, in respect of statistical analyses. The factors are extracted from the questions constituting the questionnaire (please see Fig. 2 for the corresponding question of each factor and Fig. 6 for the related elements of each factor).

TABLE. 2. Key findings - BIM users.

\begin{tabular}{|c|c|c|c|}
\hline Factor & Hypothesis & Test & Results \\
\hline $\begin{array}{l}\text { BIM } \\
\text { utilisation }\end{array}$ & $\begin{array}{l}\text { We expect that BIM utilisation increases } \\
\text { as time passes. The null hypothesis is that } \\
\text { there is no difference between the years } \\
2011,2014 \text { and } 2018 \text { in terms of BIM } \\
\text { utilisation. }\end{array}$ & $\begin{array}{l}\text { One-way } \\
\text { ANOVA }\end{array}$ & $\begin{array}{l}\text { The average BIM utilisation in } 2011 \text { is } 0.195 \text { less than } \\
\text { the average BIM utilisation in } 2014 \text {. This difference is } \\
\text { not significant at } 5 \% \text { significance level but at } 10 \% \text {. } \\
\text { Conversely, BIM utilisation in } 2018 \text { is significantly } \\
\text { different than that of in } 2011 \text {. The results suggest that } \\
\text { time is significant on BIM utilisation for the period of } \\
\text { our study since the p-value of the F-statistics is } 5 \% \\
\text { (Appendix A). }\end{array}$ \\
\hline BIM reason & $\begin{array}{l}\text { We might expect that the reasons for BIM } \\
\text { implementation such as owner/contract } \\
\text { requirement, improved productivity, } \\
\text { competitive advantage and better control } \\
\text { of time, cost and scope are increasingly } \\
\text { agreed reasons in time. }\end{array}$ & $\begin{array}{l}\text { One-way } \\
\text { ANOVA for } \\
\text { each BIM } \\
\text { implementation } \\
\text { reason (BIR) }\end{array}$ & $\begin{array}{l}\text { Except improved productivity and competitive } \\
\text { advantage, reasons are statistically non-significant. } \\
\text { Both improved productivity and competitive } \\
\text { advantage in } 2018 \text { are significantly different than those } \\
\text { of in } 2011 \text { whereas there is not a significant difference } \\
\text { between } 2011 \text { and } 2014 \text { (Appendix B). }\end{array}$ \\
\hline BIM function & $\begin{array}{l}\text { Advanced functionalities regarding cost } \\
\text { and performance analyses are expected to } \\
\text { be embraced more over the years. }\end{array}$ & $\begin{array}{l}\text { One-way } \\
\text { ANOVA for } \\
\text { each BIM } \\
\text { function (BF) }\end{array}$ & $\begin{array}{l}\text { The mean differences of project data exchange are not } \\
\text { significant at } 5 \% \text { significance level but at } 10 \% \text {. Cost } \\
\text { estimation, bill of quantities (BoQ) and building } \\
\text { performance data analysis in } 2018 \text { are significantly } \\
\text { different than those of in } 2011 \text { at } 10 \% \text { significant } \\
\text { level. Regarding } 2011 \text { users, lack of comprehensive } \\
\text { understanding of BIM could cause this snap } \\
\text { (Appendix C). }\end{array}$ \\
\hline BIM gain & $\begin{array}{l}\text { Improved design outputs, effective data } \\
\text { exchange, better communication, } \\
\text { minimised design conflicts and new } \\
\text { business opportunities are expected to be } \\
\text { the common BIM gains for } 2011,2014 \\
\text { and } 2018 \text { BIM users. }\end{array}$ & $\begin{array}{l}\text { One-way } \\
\text { ANOVA for } \\
\text { each BIM gain } \\
\text { (BG) }\end{array}$ & $\begin{array}{l}\text { The results show that there is a similar tendency } \\
\text { regarding the acquired advantages by BIM usage for } \\
\text { all years, yet, there are particular differences in } \\
\text { creativity and reliable design appraisal for } 2014 \text { and } \\
2018 \text { (Appendix D). }\end{array}$ \\
\hline $\begin{array}{l}\text { BIM } \\
\text { disadvantages }\end{array}$ & $\begin{array}{l}\text { We expect that lack of staff } \\
\text { knowledgeable in the use of BIM } \\
\text { technology as the main difficulty that } \\
\text { companies encountered, followed by lack } \\
\text { of cooperation from participating } \\
\text { stakeholders. It is also expected an } \\
\text { increase in stakeholder involvement into } \\
\text { BIM processes over the years. }\end{array}$ & $\begin{array}{l}\text { One-way } \\
\text { ANOVA for } \\
\text { each BIM } \\
\text { disadvantages } \\
\text { (BD) }\end{array}$ & $\begin{array}{l}\text { The results show that none of BIM difficulties (BD) is } \\
\text { significant at } 5 \% \text { significance level. The majority of all } \\
2011,2014 \text { and } 2018 \text { users did not feel that they } \\
\text { lacked top management support and were neutral for } \\
\text { lack of marketing. Contrary to expectations, the } \\
\text { difference of stakeholder involvement into BIM } \\
\text { processes between } 2014 \text { and } 2018 \text { is reverse } \\
\text { (Appendix E). }\end{array}$ \\
\hline
\end{tabular}




\begin{tabular}{|c|c|c|c|}
\hline Factor & Hypothesis & Test & Results \\
\hline BIM cost & $\begin{array}{l}\text { We expect that BIM software is } \\
\text { accounted for the majority of investments } \\
\text { made during the BIM implementation } \\
\text { process, as well as new/upgraded } \\
\text { hardware and BIM training. Software } \\
\text { customization/interoperability solutions } \\
\text { are expected to be the least important area } \\
\text { of BIM investment. }\end{array}$ & $\begin{array}{l}\text { One-way } \\
\text { ANOVA for } \\
\text { each BIM cost } \\
\text { (BC) }\end{array}$ & $\begin{array}{l}\text { As expected, the marketing cost of their BIM } \\
\text { capability, the average of this cost component in } 2018 \\
\text { is less than the average of it in } 2011 \text {. According to } \\
\text { one-way ANOVA, the difference between } 2011 \text { and } \\
2018 \text { is statistically significant at } 5 \% \text { level (Appendix } \\
\text { F). }\end{array}$ \\
\hline $\begin{array}{l}\text { BIM } \\
\text { satisfaction }\end{array}$ & $\begin{array}{l}\text { The overall satisfaction of BIM utilisation } \\
\text { by year is examined through BIM } \\
\text { satisfaction index, which is based on BIM } \\
\text { gain (BG) components. It is expected that } \\
\text { the more experience the BIM users have } \\
\text { the more satisfied they are. }\end{array}$ & $\begin{array}{l}\text { Regression } \\
\text { analysis for } \\
\text { BIM age and } \\
\text { year impact on } \\
\text { BIM } \\
\text { satisfaction }\end{array}$ & $\begin{array}{l}\text { BIM age and year can explain } 10 \% \text { of the variation in } \\
\text { BIM satisfaction. The model is significant at } 5 \% \\
\text { significance level since the p-value of F statistics is } \\
0.038 \text {. The effect of BIM age on BIM satisfaction is } \\
\text { significant at } 5 \% \text { significance level. However, the } \\
\text { regression analysis result claims that year's impact on } \\
\text { satisfactory is not significant at } 5 \% \text { level due to the } \\
\text { higher p-value (Appendix G). }\end{array}$ \\
\hline $\begin{array}{l}\text { BIM } \\
\text { difficulty }\end{array}$ & $\begin{array}{l}\text { To determine the impacts of BIM age and } \\
\text { year on the difficulties that companies } \\
\text { faced, BIM difficulty index is specified } \\
\text { based on BIM disadvantages. It is } \\
\text { expected that more experienced users } \\
\text { have less difficulty in using BIM. }\end{array}$ & $\begin{array}{l}\text { Regression } \\
\text { analysis for } \\
\text { BIM age and } \\
\text { year impact on } \\
\text { BIM difficulty }\end{array}$ & $\begin{array}{l}\text { BIM age and year can explain } 6.7 \% \text { of the variation in } \\
\text { BIM difficulty. The model is not significant at } 5 \% \\
\text { significance level since the p-value of F statistics is } \\
\text { greater than } 0.05 \text {. The effect of BIM age on BIM } \\
\text { difficulty is significant at } 5 \% \text { significance level, } \\
\text { however, the regression analysis result claims that } \\
\text { year's impact on satisfactory is not significant at } \% 5 \\
\text { level (Appendix H). }\end{array}$ \\
\hline BIM level & $\begin{array}{l}\text { The level of experience of using BIM is } \\
\text { examined to understand whether it has an } \\
\text { impact on BIM function. It is expected } \\
\text { that as BIM level increases, the } \\
\text { functionalities that companies use } \\
\text { improve. }\end{array}$ & $\begin{array}{l}\text { One-way } \\
\text { ANOVA for } \\
\text { each BIM } \\
\text { function }\end{array}$ & $\begin{array}{l}\text { There are meaningful differences for cost estimation } \\
\text { and building performance data analysis according to } \\
\text { BIM level. The average of cost estimation in BIM } \\
\text { experts (BIM Level 4) is greater than the average of } \\
\text { this function in BIM level } 1 \text { (beginner) and BIM level } \\
2 \text { (intermediate) users. The mean differences of cost } \\
\text { estimation are statistically significant at 5\% } \\
\text { significance level. There is no significant difference } \\
\text { between BIM level } 3 \text { (advanced) and BIM level } 4 \text { in } \\
\text { terms of cost estimation. The average of building } \\
\text { performance data analysis in BIM experts (BIM Level } \\
\text { 4) is greater than that of in BIM level } 1 \text { (beginner). } \\
\text { The p-value of } 2.1 \% \text { is statistically significant at } 5 \% \\
\text { significance level (Appendix I). }\end{array}$ \\
\hline
\end{tabular}

BIM utilisation has increased over the years, yet, the awareness of the need for its usage remains limited and the application of BIM tools tends to be implemented by major firms rather than expanding to all levels of the industry. The following sections help assess the BIM experience and adoption level of the companies whilst BIM reason and non-BIM reason summarise the drivers and barriers to BIM usage respectively.

BIM reason: Coordination and competitive advantage sharing similarity with previous studies (Bosch-Sijtsema et al 2017 and Babatunde et al 2020), are the top ranked sources of motivation to BIM usage for all three years. Despite its substantial degree, improved productivity has less influence on the companies to adopt BIM over the years. Due to the government procurement strategy, owner/contract requirements have become one of the accelerating reasons for using BIM. Classified as neutral drivers by all participants; better control of time, cost and scope are slightly different from those of the earlier studies (Chan et al 2019 and Babatunde et al 2018), especially from the cost aspect. Multi user simultaneous input and reducing waste are also the driving forces specified for BIM utilisation.

BIM function: Despite the common adoption of 3D visualization, clash detection and conflict resolution, further roles that help estimate cost and BoQ or perform energy analyses are also specified by the users as other functions of BIM. Whereas the vast majority of companies argued that BIM facilitated visualization of architectural design, clash detection and conflict resolution, and project data exchange, many users were either neutral or negative about BIM's power on cost estimation, BoQ and building performance data analysis in all years of the study. New adopters predominantly apply BIM for clash detection and conflict resolution, visualization and data exchange, though a considerable percentage of long-time users stated that cost estimation, bill of quantities (BoQ) and building performance data analyses are also functions that they utilise BIM technology for.

BIM gain: Referring to one of the most commonly specified BIM functions, minimised design conflicts is the top recognised BIM benefit despite showing a 10\% decrease from 2011 to 2018, followed by improved design outputs, 
improved communication and project stakeholder satisfaction. These results match the findings of Yang and Chou (2018). Whilst effective project data exchange is a rising acquired advantage by BIM usage over the years, vice versa for new business opportunities.

BIM disadvantages: In spite of a declining rate in time, lack of staff knowledgeable in the use of BIM technology is the main difficulty that companies encountered for all years. Lack of stakeholder cooperation as the next barrier to BIM usage is along the lines of the previous researches (Alreshidi et al 2018, Chan et al 2019 and Elagiry et al 2019). Disparately from Son et al (2015) and Chien et al (2014), the majority of all 2011, 2014 and 2018 users did not feel that they lacked top management support. Comparably, neither lack of BIM provider support nor lack of marketing are commonly counted as obstacles for BIM. Whereas problems related to existing procedures/processes and digital data exchange gain prominence over the years, lack of established BIM standards fall of the radar.

BIM cost: Like any other technological investments, BIM requires high upfront costs during its implementation process. BIM software is the top cost component for all companies for the years of 2011, 2014 and 2018. New/upgraded hardware and BIM training as the next, are less influential after 2014. BIM users from all years are neutral about developing collaborative BIM processes with external parties. Software customization/interoperability solutions are considered to be the least important area of BIM investment.

\subsubsection{Non-BIM users}

The reliability analysis for the scale consisting of 11 questions applied to the non-BIM users who also have no intention to implement BIM showed that the questionnaire has moderate reliability, with a Cronbach's Alpha score of 0.729 . The hypotheses regarding non-BIM users concern the impact of year on

- $\quad$ reasons for not using BIM;

- $\quad$ reasons for deciding to use BIM;

- $\quad$ requirements for BIM adoption.

Table 3 summarises the key findings of each factor concerning non-BIM users (please see Fig. 2 for the corresponding question of each factor and Fig. 6 for the related elements of each factor).

TABLE. 3. Key findings - non-BIM users.

\begin{tabular}{|c|c|c|c|}
\hline Factor & Hypothesis & Test & Results \\
\hline $\begin{array}{l}\text { Non-BIM } \\
\text { reason }\end{array}$ & $\begin{array}{l}\text { We expect that the main reasons for not using } \\
\text { BIM are not enough demand from clients and/or } \\
\text { other firms, cost related obstacles including both } \\
\text { software and hardware and lack of BIM qualified } \\
\text { staff. It is expected that the positive responses for } \\
\text { not enough demand from clients and/or other } \\
\text { firms decrease over the years. }\end{array}$ & $\begin{array}{l}\text { One-way } \\
\text { ANOVA } \\
\text { for each } \\
\text { non-BIM } \\
\text { reason }\end{array}$ & $\begin{array}{l}\text { The average of 'not enough demand' in } 2014 \text { is } \\
\text { greater than the average of that in } 2011 \text { and the } \\
\text { difference between two are statistically } \\
\text { significant. However, there is no difference } \\
\text { between the responses for } 2011 \text { and } 2018 \text {, and } \\
2014 \text { and } 2018 \text {. Amongst the reasons, } \\
\text { 'functionality doesn't apply well enough to what } \\
\text { we do' and 'cost related obstacles' are also } \\
\text { significantly different. The average of cost related } \\
\text { obstacles in } 2018 \text { is less than those of in } 2011 \text { and } \\
2014 \text {. The p-values suggest that the mean } \\
\text { differences are significant at an alpha level of } \\
0.05 \text { (Appendix J). }\end{array}$ \\
\hline $\begin{array}{l}\text { Non-BIM } \\
\text { plan reason }\end{array}$ & $\begin{array}{l}\text { We might expect that collaboration, cooperation } \\
\text { and coordination are the main reasons for deciding } \\
\text { to implement BIM technology as well as } \\
\text { owner/contract requirements, improved } \\
\text { productivity and competitive advantage. Improved } \\
\text { productivity and competitive advantage are also } \\
\text { expected to be instrumental for their decision to } \\
\text { implement BIM. }\end{array}$ & $\begin{array}{l}\text { One-way } \\
\text { ANOVA } \\
\text { for each } \\
\text { non-BIM } \\
\text { plan reason }\end{array}$ & $\begin{array}{l}\text { Owner/contract requirements, coordination, } \\
\text { cooperation, collaboration and better control of } \\
\text { scope are the reasons that have statistically } \\
\text { significant differences (Appendix K). }\end{array}$ \\
\hline $\begin{array}{l}\text { Non-BIM } \\
\text { plan adoption } \\
\text { requirements }\end{array}$ & $\begin{array}{l}\text { We expect more positive response to the 'enough } \\
\text { physical resources' question than to 'enough } \\
\text { financial resources' including staff training, } \\
\text { existing hardware and software upgrade if not } \\
\text { compatible for BIM. Sufficient time for } \\
\text { preparation and new business potential are } \\
\text { expected to be less preferred. }\end{array}$ & $\begin{array}{l}\text { One-way } \\
\text { ANOVA } \\
\text { for each } \\
\text { non-BIM } \\
\text { plan } \\
\text { adoption } \\
\text { requirement }\end{array}$ & $\begin{array}{l}\text { Except the mean difference of enough physical } \\
\text { resources between } 2014 \text { and } 2018 \text {, there are no } \\
\text { meaningful differences among BIM adoption } \\
\text { requirements (Appendix L). }\end{array}$ \\
\hline
\end{tabular}


Non-BIM reason: Consistent with the findings of Charef et al (2019), lack of demand is the top ranked barrier to the acceptance of BIM for all years despite its decreasing tendency, followed by cost of transition. Initial investment cost prevents small and medium sized enterprises from adopting BIM technology. The other main concerns are lack of understanding and lack of capable staff. Not see the benefits, no time for evaluation and lack of legal obligation are less decisive after 2014 whereas the impact of not applicable to business functions is decreasing over the years.

Non-BIM plan reason: Improving the productivity and gaining competitive advantage are the top-rated drivers for the participants planning BIM implementation. Distinctively, 2014 respondents are the least interested in all motivational reasons and there is a dramatic jump subsequently especially for coordination, cooperation and better control of scope.

Non-BIM plan adoption requirements: Despite its declining rate after 2014, enough physical resources are the most available condition for all companies to adopt BIM. With a similar trend, other conditions (new business potential, sufficient time for preparation and enough financial resources) are also unavailable for most of the companies.

\subsubsection{Key learning points}

Going beyond all these numerical results, this comparison amid three years provides to observe the changes within the architectural offices in terms of BIM aspects. The key learning points are:

- Motivational reasons to use BIM have shifted from external forces (e.g. contract requirement, competitive advantage) to the requirements by the nature of construction projects (e.g. effective teamwork, collaboration, cooperation, better control of scope). This supports that the traditional ways of AEC and FM industries will transform into digitalisation in near future.

- Inferred from the open-ended answers, recent respondents practice BIM more thoroughly than early ones. It is possible to say that BIM usage has gone beyond visualisation and conflict detection, and it is used for advanced analyses through the formation of data to meaningful information.

- The beneficiaries have realised that using BIM is achieving proper data exchange between the stakeholders and effective communication, which is more than a $3 \mathrm{D}$ model of the project.

- $\quad$ Accordingly, the challenges faced by have also changed from peripheral issues (e.g. lack of top management support, lack of BIM staff, lack of stakeholder cooperation and lack of BIM standards) to more central concerns (e.g. procedure problems and technical problems affecting the precise data exchange).

- $\quad$ The barriers prevent from BIM adoption have also differentiated into more concrete obstacles (e.g. not applicable to business functions) from generic ones such as lack of qualified staff or investment costs. Regardless of BIM usage, BIM awakening and comprehension have increased between three years among AEC people.

- $\quad$ Pursuant to the results, there has been a rise in the level of BIM experience and adoption over the years. It can be inferred that the overall BIM consciousness level has become from low to mid based on recent consistent and deliberate feedbacks in comparison with more varying responses in 2011 and 2014.

- $\quad$ Even though these arguments reflect a small fraction, as a general inference we can say that the industry tries to keep up with the changing way of BIM trend since the longer the awareness stage the more missed opportunities.

\section{EVALUATION FRAMEWORK}

Increased attention to BIM among practitioners is undoubtedly meaningful for the dissemination of the technology, though this alone is not enough for a thorough acceptance. A sustainable BIM implementation can be achieved through a comprehensive evaluation of BIM values. In order to assist the successful adoption and utilisation of BIM, this study proposes an evaluation framework for decision makers to assess their BIM competency (Fig. 6). The proposed framework aims to elaborate in the great scheme of BIM related subjects within a company, 
including formation, progress and outcome processes. Each of these processes consists of components and questions to be answered. For instance, in the first stage where the investment decision is made or not, the inputs are listed and objectives are determined so that why, where and when to make an impact can be specified. The elements of each component are derived from the questionnaire carried out in this study (e.g. objective includes the reasons for implementing BIM technology). The relevant responses partaking in the questionnaire are grouped under the related component of the evaluation framework. In other words, the questionnaire forms a basis and is used as a case study for the evaluation framework. The elements of each component can be expanded and/or switched according to the existing conditions.

Complementing each other, the components of the framework support to systematically investigate the value of BIM. Based on the specified objectives, outputs and outcomes, the participants are engaged. The impacts and difficulties help obtain accurate evidence for the entire process. The connected steps include: (1) After taking initial investment idea, the reasons for the adoption, level of change and time to transfer are determined and adoption plan is prepared based on the inputs, objective and available adoption requirements; (2) activities and tasks are assigned to the people, technology, process and cost aspects for the progress of technology utilisation as well as the difficulties encountered are recorded; (3) in order to measure the performance, the functions that BIM is used for, outcomes achieved and impacts gained are identified; (4) for each process, indicators are set and how to measure soft outcomes is planned. Stakeholder participation throughout the entire cycle plays a key role in obtaining real evidence for validation and feedback of the framework.

Covering all the main lines and bases for the entire BIM adoption process, such a framework provides a holistic approach. Its extendable structure allows the users to enhance it according to their needs, targets, specific problems and feedback from all other stakeholders. To relate the reasons and consequences of BIM utilisation, issues such as what kind of impact is intended to make, its timing and scale and, how to establish and measure this impact should be considered. The success of BIM adoption relies on well-discussed arguments.

\section{CONCLUSION}

Changing the dynamics of an architectural organisation is considerably challenging unless it is required or the conditions are favourable, yet, there has been a trend of increasing BIM utilisation across the UK AEC industry due to its power as a tool for addressing some of the main issues (e.g. greater collaboration and exchange of project data in design and construction management). Concurrently, the confidence in BIM knowledge has risen to midlevels even it is limited. Considering the near future of digital transformation of the industry, efforts should be taken to spread and improve the BIM uptake by raising awareness of collaborative working. Worldwide, there are various international BIM developments and legislative regulations that encourage BIM adoption, interoperability and coordination among stakeholders of the AEC/FM industry. The more governments encourage BIM in the industry, the faster dissemination can be achieved. Success in government projects can serve as an example to the private sector, leading to more rapid adoption of BIM throughout the industry (e.g. the NBS BIM survey allows us to gauge how successful the BIM mandate has been) (Malleson, 2018). As an example, the NBS BIM survey shows that $4 \%$ believed that the mandate had been very successful, with a further $37 \%$ viewing it as 'quite successful' while many noted how the mandate has given the industry the push towards BIM that it needed.

In particular, government-supported incentives can diminish cost related barriers. Both quantitative and qualitative approaches should be combined to propose successful BIM adoption and implementation strategies. By analysing and comparing the BIM uptake over a period, this research shows that the main factors affecting BIM adoption are initial investment cost, cost and time spent on staff training for a thorough benefit, a lack of understanding its capabilities, fear to adopt due to the perception of being too sophisticated for day to day use. The evaluation framework developed based on this questionnaire, reaches beyond simple assessment to comprise the motivation, benefits, functions, difficulties and gains of BIM.

On the other hand, as Barker (2018) stated, it is important to note that the growing potential of data analytics, Artificial Intelligence (AI), machine-learning, Internet of Things (IoT) and integration with Geographic Information System (GIS) platforms means that a narrow focus on BIM Level 2 is not the only way forward for the built environment where infrastructure, buildings, digital media and systems must all converge if the future is smarter cities and communities. 


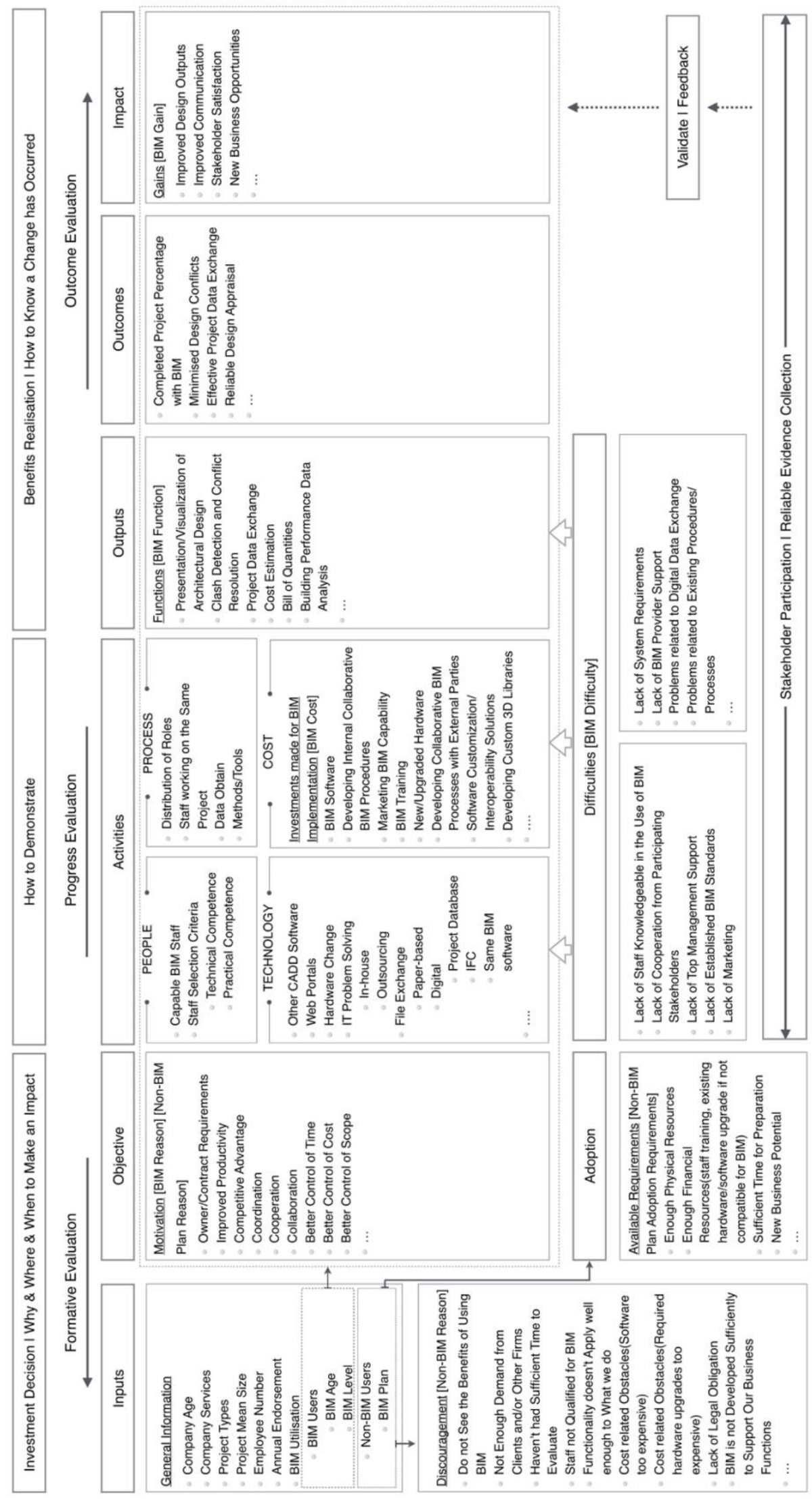

FIG. 6. Evaluation framework. 


\section{ACKNOWLEDGMENTS}

The authors would like to thank Dr Wilfred Matipa who assisted in the collection of the data.

\section{DATA AVAILABILITY STATEMENT}

The statistical data that support the findings of this study are available from the corresponding author, upon reasonable request. The data presented in appendices are available as supplemental online material.

\section{REFERENCES}

Ahmed A.L. and Kassem, M. (2018). A unified BIM adoption taxonomy: Conceptual development, empirical validation and application, Automation in Construction, Vol. 96, 103-127.

Alreshidi E., Mourshed M. and Rezgui Y. (2018). Requirements for cloud-based BIM governance solutions to facilitate team collaboration in construction projects, Requirements Engineering, Vol. 23, No. 1, 1-31.

Babatunde S.O., Ekundayo D., Adekunle A.O. and Bello W. (2020). Comparative analysis of drivers to BIM adoption among AEC firms in developing countries, Journal of Engineering, Design and Technology, Vol. ahead-of-print, No. ahead-of-print.

Babatunde S.O., Ekundayo D., Babalola O. and Jimoh J.A. (2018). Analysis of the drivers and benefits of BIM incorporation into quantity surveying profession, Journal of Engineering, Design and Technology, Vol. 16, No. 5, 750-766.

Bain D. (2019). UK BIM survey 2019 findings, National BIM Report. Accessed 5 January 2020. https://www.thenbs.com/knowledge/national-bim-report-2019

Barker P. (2018). From UK to the world - Making BIM work internationally, National BIM Report. Accessed 3 February 2019. https://www.thenbs.com/knowledge/the-national-bim-report-2018

Barlish K. and Sullivan K. (2012). How to measure the benefits of BIM-A case study approach, Automation in Construction, Vol. 24, 149-159.

Blay K.B., Tuuli, M.M. and France-Mensah J. (2019). Managing change in BIM-level 2 projects: Benefits, challenges, and opportunities, Built Environment Project and Asset Management, Vol. 9, No. 5, 581-596.

Bosch-Sijtsema P., Isaksson A., Lennartsson M. and Linderoth H.C.J. (2017). Barriers and facilitators for BIM use among Swedish medium-sized contractors-"We wait until someone tells us to use it", Visualization in Engineering, Vol. 5, Article No. 3.

Building and Construction Authority. (2018). Technology Adoption: Building Information Model (BIM) Fund, Accessed 5 January 2019. https://www.bca.gov.sg/BIM/bimfund.html

Chan D. W.M., Olawumi T.O. and Ho A. M.L. (2019). Perceived benefits of and barriers to building information modelling (BIM) implementation in construction: The case of Hong Kong, Journal of Building Engineering, Vol. 25, 100764.

Charef R., Emmitt S., Alaka H. and Fouchal F. (2019). Building information modelling adoption in the European Union: An overview, Journal of Building Engineering, Vol. 25, 100777.

Chien K.-F., Wu Z.-H. and Huang S.-C. (2014). Identifying and assessing critical risk factors for BIM projects: Empirical study, Automation in Construction, Vol. 45, 1-15.

Davies R. and Harty C. (2013). Implementing 'Site BIM': A case study of ICT innovation on a large hospital project, Automation in Construction, Vol. 30, 15-24.

Ding Z., Zuo J., Wu J. and Wang J.Y. (2015). Key factors for the BIM adoption by architects: A China study, Engineering, Construction and Architectural Management, Vol. 22, No. 6, 732-748.

Georgiadou M.C. (2019). An overview of benefits and challenges of building information modelling (BIM) adoption in UK residential projects, Construction Innovation, Vol. 19, No. 3, 298-320. 
Ghaffarianhoseini A., Tookey J., Ghaffarianhoseini A., Naismith N., Azhar S., Efimova O. and Raahemifar K. (2017). Building information modelling (BIM) uptake: Clear benefits, understanding its implementation, risks and challenges, Renewable and Sustainable Energy Reviews, Vol. 75, 1046-1053.

Giacomo E.D. (2015). BIM, trends from all around the world, European BIM Summit, Accessed 20 February 2019. http://numerique.tech.fr/Barcelona_BIM_Summit_Feb_13th_EDG150213_P.pdf

Government Construction Strategy. (2012). Government construction strategy implementation report, Accessed 13 September 2018.

https://www.gov.uk/government/uploads/system/uploads/attachment_data/file/61151/GCS-One-Year-OnReport-and-Action-Plan-Update-FINAL_0.pdf

Eadie R., Browne M., Odeyinka H., McKeown C. and McNiff S. (2015). A survey of current status of and perceived changes required for BIM adoption in the UK, Built Environment Project and Asset Management, Vol. 5, No. 1, 4-21.

Elagiry M., Marino V., Lasarte N., Elguezabal P. and Messervey T. (2019). BIM4Ren: Barriers to BIM implementation in renovation processes in the Italian market, Buildings, Vol. 9, No. 9, 200.

Evans J. R. and Mathur A. (2005). The value of online surveys, Internet Research, Vol. 15, No. 2, $195-219$.

Hermund A. (2009). Building information modeling in the architectural design phases: And why compulsory BIM can provoke distress among architects, Proceedings of the 27 th Conference on Education and Research in Computer Aided Architectural Design in Europe (eCAADe), Istanbul, September 16-19.

Jensen P.A. and Jóhannesson E. I. (2013). Building information modelling in Denmark and Iceland, Engineering, Construction and Architectural Management, Vol. 20, No. 1, 99-110.

Jin R., Hancock C., Tang L., Chen C., Wanatowski D. and Yang L. (2017). Empirical study of BIM implementation-based perceptions among Chinese practitioners, Journal of Management in Engineering, Vol. 33, No. 5, 04017025.

Jung W. and Lee G. (2015). Slim BIM charts for rapidly visualizing and quantifying levels of BIM adoption and implementation, Journal of Computing in Civil Engineering, Vol. 30, No. 4, 04015072.

Lee S. and Yu J. (2015). Comparative study of BIM acceptance between Korea and the United States, Journal of Construction Engineering and Management, Vol. 142, No. 3, 05015016.

Malleson A. (2018). National BIM survey: Summary of findings, National BIM Report. Accessed 3 February 2019. https://www.thenbs.com/knowledge/the-national-bim-report-2018

Matta C. (2016). 3D-4D building information modeling, General Services Administration (GSA). Accessed 25 August 2018. www.gsa.gov/bim

Mulenga K. and Han Z. (2010). Building information modelling: Optimizing BIM adoption and mindset change: Emphasize on a construction company, MSc dissertation., Chalmers University of Technology.

Papadonikolaki E. (2018). Loosely coupled systems of innovation: Aligning BIM adoption with implementation in Dutch construction, Journal of Management in Engineering, Vol. 34, No. 6, 05018009.

Sackey E., Tuuli M.M. and Dainty A. (2014). Sociotechnical systems approach to BIM implementation in a multidisciplinary construction context, Journal of Management in Engineering, Vol. 31, No. 1, A4014005.

Samuelson O. and Björk B.-C. (2014). A longitudinal study of the adoption of IT technology in the Swedish building sector, Automation in Construction, Vol. 37, 182-190.

Sanchís Pedregosa C., Vizcarra Aparicio J.M. and Leal Rodríguez A.L. (2020). BIM: A technology acceptance model in Peru, Journal of Information Technology in Construction (ITcon), Vol. 25, 99-108.

Smith P. (2014). BIM implementation-Global strategies, Procedia Engineering, Vol. 85, 482-492.

Smits W., Buiten M. and Hartmann T. (2017). Yield-to-BIM: Impacts of BIM maturity on project performance. Building Research \& Information, Vol. 45, No. 3, 336-346. 
Son H., Lee S. and Kim C. (2015). What drives the adoption of building information modeling in design organizations? An empirical investigation of the antecedents affecting architects' behavioural intentions, Automation in Construction, Vol. 49, 92-99.

Tsai M.-H., Mom M. and Hsieh S.-H. (2014). Developing critical success factors for the assessment of BIM technology adoption: Part I. Methodology and survey, Journal of the Chinese Institute of Engineers, Vol. 37, No. 7, 845-858.

Wang G. and Song J. (2017). The relation of perceived benefits and organizational supports to user satisfaction with building information model (BIM), Computers in Human Behavior, Vol. 68, 493-500.

Wu W. and Issa R.R.A. (2013). BIM education and recruiting: Survey-based comparative analysis of issues, perceptions, and collaboration opportunities, Journal of Professional Issues in Engineering Education and Practice, Vol. 140, No. 2, 04013014.

$\mathrm{Xu}, \mathrm{H}$., Feng J. and Li S. (2014). Users-orientated evaluation of building information model in the Chinese construction industry, Automation in Construction, Vol. 39, 32-46.

Yang J.-B. and Chou H.-Y. (2018). Mixed approach to government BIM implementation policy: An empirical study of Taiwan, Journal of Building Engineering, Vol. 20, 337-343. 